Bull. Fac. Agric., Cairo Univ., 67: 141-152 (2016).

\title{
EFFECT OF SOME HERBICIDES ON DODDER, GREEN FORAGE, YIELD, NODULATION AND DETERMINATION OF THEIR RESIDUES IN CLOVER PLANTS AND SOIL.
}

\author{
(Received: 25.5.2016) \\ By \\ I. E. Soliman and A. M. Hamza \\ Weed Research Central Laboratory, Agricultural Research Center Giza, Egypt. \\ * Pesticides Department, Faculty of Agriculture. Kafrelsheikh University, Egypt.
}

\begin{abstract}
Two field experiments were conducted during 2013 / 2014 and 2014 / 2015 seasons at Sakha Agriculture Research Station, Egypt to investigate the efficacy of some herbicides i.e. glyphosate and propyzamide in addition to the hand pulling for controlling dodder weed (Cuscuta planiflora ten.) and their effects on some growth characters, seed yield of clover plants (Trifolium alexandrinum L.) and herbicide residues in the soil and clover plants. Results indicated that glyphosate at the rates of 0.07 and 0.1 1/fed showed excellent control of dodder with 97.7 and $98.9 \%$ control, followed by Propyzamide at the rate 0.75 and 1.0 1/fed with 83.0 and $88.0 \%$ control, respectively. Dodder infestation caused a great decrease in plant height, fresh, dry weight and seed yield of clover plants. Hand pulling treatment was not enough to control dodder, (51\% control at the $3^{\text {rd }}$ cut).

Clover plants infested with dodder showed the lowest chlorophyll a, b and the highest carotene content. Data also, cleared that different herbicide treatments showed least decreased on chlorophyll a, $\mathrm{b}$ and the increased carotene content compared to un-infested and un-treated plants. Data also, revealed that herbicide treatments slightly decreased protein content of clover. Gglyphosate treatments increased the number and dry weight of nodules, while propyzamide showed an opposite when compared to un-infested and un-treated plants. The glyphosate residue became undetected in the soil after 40 days from application. At the end of the experiment there were no residue in clover plants. The times for $50 \%$ loss of initial propyzamide in soil were 23 and 26 days. The loss of initial concentrations reached (98.91 and 99.1\%). At the end of experiment (60 days) there were no propyzamide residues in the clover plants. These results indicated that under heavy invested soil with dodder, it is possible to use each of (glyphosate at $0.07 \mathrm{l} / \mathrm{fed}$ or propyzamide at $0.1 \mathrm{l} / \mathrm{fed}$ ) for dodder weed control. These treatments gave the economically best dodder control and increased clover yield and it's components, without any harm effect on clover plants or on the soil.
\end{abstract}

Key words: Clover, Trifolium alexandrianum, Dodder, Cuscuta planiflora ten., propyzamid, glyphosate, Residues, Hand combing.

\section{INTRODUCTION}

Egyptian clover (Trifolium alexandrinum L.), which is locally named berseem, is the main forage crop for animals in Egypt. It has a super qualitative characters such as high nutritive value and crude protein content.

Dodder (Cuscuta planiflora ten.) is known to be among the main pests attacking the Egyptian clover in Egypt, while other species of dodder have been reported in some other plants in different locations in Egypt (Tackholem, 1974). Al-Shair (1989) mentioned that (Cuscuta planiflora) decreased (Trifolium alexandrinum L.) fresh and dry weight at the first and second cuts, the number of seed in florescence, seed yield and germination percentage and increased seed number/g.

Satisfactory dodder control in clover and alfalfa were obtained by glyphosate (Heap, 1992). Glyphosate herbicide had no adverse effect on growth and development of berseem (Bhan and Balyan, 1982).

Abd El-Wahed (1996) found that glyphosate at (400 g a.i./fed) gave $(94-97 \%)$ control of ( Cuscuta spp.) in Egyptian clover. The half rate (200 g a.i./fed) gave $(90-94 \%)$ control, while glyphosate at (100 and $50 \mathrm{~g}$ a.i./fed) was less effective on (Cuscuta spp.) than the first and 
second rate. Also, Molnar et al. (1998) showed that Roundup (glyphosate) at 0.8 1/ha gave (94\%) control of (Cuscuta planiflora). Zaki et al., (1998) applied glyphosate $(1.0-1.25$ 1/ha) on Egyptian clover (Trifolium alexandrinum) to control dodder. Soliman and Abd El-Hamid (2009) and Soliman (2009) indicated that (C. planiflora) was very sensitive to propyzamide at $1.0 \mathrm{~kg} / \mathrm{fed}$ and glyphosate at $0.06 \mathrm{l} / \mathrm{fed}$, where, these treatments reduced the fresh weight of dodder by 96.2 and $90.3 \%$, respectively.

Kontsiotou (1979) reported that the best control of (Cuscuta spp.) in lucerne yield was given by propyzamide at $300 \mathrm{ml} / \mathrm{ha}$ and chlorthal dimethyl at $1.1 \mathrm{l} / \mathrm{ha}$ applied preemergence. Hammouda et al. (1989) indicated that dodder control increased as the rate of pronamide increased up to $1.25 \mathrm{~kg}$ a.i./fed when used as pre and post-emergence in Egyptian clover. Ahmed et al. (1995) indicated that glyphosate herbicide showed good control of dodder. Also, the parasitic weed caused a great reduction in height of the plant, fresh and dry weights of clover plants.

Al-Menoufi and Hassan (1977) found that the protein content, yield of fresh and dry matter and the nutritive value of plant materials were reduced in Egyptian clover infested with $(C$. planiflora.). Soliman (2002) and Soliman and Abd El-Hamid (2009) showed that the parasitic weed dodder caused a great reduction in fresh weight of clover. Dodder weed reduces the crude protein comparing with healthy plants. Also, the results cleared that the herbicides showed least effective on protein content.

In relation to legume plant inoculation, the use of herbicides injures or destroys the rhizobia, therefore, the influence of herbicides on weeds, rhizobia, nodulation, symbiotic free of weeds all the season. (Timothy et al., 1978). Concerning rhizobia, some herbicides don't have no effect and some are harmful. Details as to inhibiting level are confused by the fact that species and strains within species differ considerably in their sensitivity to even on herbicide and because the result is likely to be affected by conditions and time of inoculation. Hammouda et al., (1989) found that preemergence pronamide treatments showed slight decrease in both numbers and dry weight of nodules than untreated plots. All pronamide concentrations tested remedy reduced the population levels in the rhizosphere soil. However, such a reduction in the rhizobial colonization due to pronamide herbicide was relatively less marked in the post-emergence method compared to that in pre-emergence one.

The aim of the present study was to investigate the effects of herbicides on dodder weed control, green forage, nodulation, seed yield of Egyptian clover and determine herbicide residues in soil and clover plants.

\section{MATERIALS AND METHODS}

Two field experiments were conducted at Sakha Agriculture Research Station, Kafrelsheikh, during 2013/2014 and 2014/2015 seasons, to study the effect of some herbicides on controlling dodder (Cuscuta planiflora) in Egyptian clover (Trifolium alexandrinum L.) c.v. Meskawy, clover yield, nodulation and their residues in clover plants and soil. The soil was clay in both seasons as shown in Table (1).

Dodder seeds were mixed with soil at $5 \%$ of clover seeds, $(\mathrm{w} / \mathrm{w})$. The seeds were broadcasted on the soil at rate of $24 \mathrm{~kg} / \mathrm{fed}$ in Oct. 15 and 20 for the first and second season, respectively. The plot area was $10.5 \mathrm{~m}^{2}$ and artificially infested by

Table (1): Mechanical and chemical analysis of the experimental soil.

\begin{tabular}{|c|c|c|c|c|c|c|c|c|c|}
\hline Seasons & $\begin{array}{c}\text { Organic } \\
\text { matter \% }\end{array}$ & $\begin{array}{c}\text { Soil } \\
\text { PH }\end{array}$ & $\begin{array}{c}\text { Sand } \\
\mathbf{\%}\end{array}$ & $\begin{array}{c}\text { Silt } \\
\mathbf{\%}\end{array}$ & $\begin{array}{c}\text { Clay } \\
\mathbf{\%}\end{array}$ & $\begin{array}{c}\text { Textural } \\
\text { class }\end{array}$ & $\begin{array}{c}\mathbf{N}, \\
\mathbf{p p m}\end{array}$ & $\begin{array}{c}\mathbf{P} \\
\mathbf{p p m}\end{array}$ & $\begin{array}{c}\mathbf{K} \\
\mathbf{p p m}\end{array}$ \\
\hline $2013 / 2014$ & 1.55 & 8.10 & 15.78 & 35.93 & 48.29 & Clay & 20.83 & 19.66 & 28.17 \\
\hline $2014 / 2015$ & 1.33 & 8.06 & 13.89 & 35.99 & 50.02 & Clay & 18.00 & 20.66 & 27.90 \\
\hline
\end{tabular}

nitrogen fixation and legume plant was reported by several workers (Abd Alla et al., 1985 and El-Hawary et al., 1986).

Generally, herbicides are different in their effect on each of weed and rhizobia with respect to some weeds. The long persistence of some herbicides is well desired to preserve the soil dodder seeds. The experiments were laid out in complete randomized block design with four replications, where seven treatments were involved as follows:

1-Glyphosate 48\% WSC [N-(Phosphonomethyle glycine) - isopropylammonium] known commercially as (Roundup) was applied at 
the rate of $0.07 \quad 1 / f e d$ after two weeks from cutting and with the appearance of dodder.

2- Glyphosate $48 \%$ WSC (Roundup) at the rate of $0.1 \mathrm{l} / \mathrm{fed}$ after two weeks from cutting and with the appearance of dodder.

3- Propzamide $40 \%$ SC [3,5 - dichloro - N - (1 - dimethyl -2 - propynyl) benzamide] known commercially as (Kerb Flow) was applied at the rate of $0.751 / \mathrm{fed}$, surface application (after sowing and before irrigation).

4- Propzamide $40 \%$ SC (Kerb Flow) was applied at the rate of $0.1 \mathrm{l} / \mathrm{fed}$, surface application (after sowing and before irrigation).

5- Hand pulling .

6- Un-infested control

7- Infested control

Herbicides in both field experiments were sprayed by knapsack sprayer $\mathrm{CP}_{3}$ with water volume of 200 liters per Fadden. All agronomic practices in clover as land preparation, fertilization and irrigation were applied as recommended.

\subsection{Cutting Dates}

Three cuts were taken to determine the fresh and dry weights for clover (ton/fed) and dodder $\left(\mathrm{g} / \mathrm{m}^{2}\right)$. The first cut was taken after 60 days from sowing. The second and third cuts were taken after 55 days from the first cut, while the fourth cut was left to determine seed yield ( $\mathrm{kg} / \mathrm{fed})$.

2.2.The collected data were recorded as follows:

\subsubsection{On dodder weed}

1- Fresh weight $\left(\mathrm{g} / \mathrm{m}^{2}\right)$

2- Dry weight $\left(\mathrm{g} / \mathrm{m}^{2}\right)$.

\subsubsection{On clover}

1- Plant height $(\mathrm{cm})$.

2- Fresh weight (ton/fed).

3- Dry weight (ton/fed).

The samples were taken after each cutting to determine the fresh and dry weight (ton/fed) for clover and $(\mathrm{g} / \mathrm{m} 2)$ for dodder. To evaluate the herbicidal action, the samples of dodder were randomly collected by hand pulling from each plot ( using 1.0 m quadrate), while the seed yield of clover was determined on the whole plot basis, percentage of reduction $(\mathrm{R} \%)$ was calculated according to Topps and Wain (1957) Formula as follows:

Where:

$$
\mathrm{R} \%=(\mathrm{A}-\mathrm{B}) / \mathrm{A} \times 100
$$

$\mathrm{A}=$ The fresh and dry weights of dodder in untreated plots.
$\mathrm{B}=$ The fresh and dry weights of dodder in treated plots.

\subsection{Crude Protein}

Nitrogen was determined according to the methods outlined by A.O.A.C. (1980) in representative samples of the dried forage for each treatment. Crude protein was calculated by multiplying total nitrogen x 6.25 .

\subsection{Chlorophyll and carotene contents}

Chlorophyll and carotene in leaves of clover were measured according to Sweeny and Martin (1961). Chlorophyll a, b and carotene were recorded as mg chlorophyll /gm sample (fresh weight).

\subsection{Nodulation growth}

The clover seeds were mixed immediately before sowing with fresh Rhizobium trifolii inoculum, prepared in the Soil Microbiology Division, Sakha Agriculture Station. At each cutting the nodules of ten clover plants were separated, counted, dried and weighed. The most probable number of Rhizobium trifolii from each treatment was estimated using the plant infection method (Vincent, 1970).

\subsection{Residues determination}

From each treatment, plant parts and soil samples were taken after zero time ( 72 hours for propyzamide and 24 hours for glyphosate), 10, 20, 30, 40 and (50 and 60) days after application. The residues of glyphosate and propyzamide herbicides in the soil and clover plants were extracted according to the method of El-Beit et al. (1978). The active ingredients of glyphosate and propyzamide were determined by HPLC instrument according to the method of Luke et al. (1981).

\subsection{Statistical analysis}

The collected data were statistically analyzed according to Sendecor and Cochran (1981). the treatment means were compared by Least Significant Differences (LSD) test at $(\mathrm{p}<0.05)$.

\section{RESULTS AND DISCUSSION \\ 3.1. Effect of weed control treatments on fresh and dry weights of dodder}

Fresh and dry weights of dodder as affected by different herbicide treatments are presented in Table (3). The available results revealed clearly that the fresh and dry weights of dodder were significantly affected by herbicide treatments.

In the first cut the highest efficiency in decreasing fresh and dry weights of dodder was obtained from propyzamide at the rate $1.0 \mathrm{l} / \mathrm{fed}$ 
and glyphosate at the rate $0.07 \quad 1 / f e d$. On the other hand, the highest fresh and dry weights of dodder were recorded with hand combing treatment as compared to the control infested treatment. The same trend was observed in the second and third cuts. These results are in line with results of Sher and Shad (1989) and Soliman (2002 and 2009) who reported that manual control (hand plucking) failed to give effective control of (Cuscuta spp.). In this respect, the effect of herbicides on dodder is in agreement with those obtained by Ahmed et al. (1995) and Soliman (2002).

\subsection{Effect of weed control treatments on clover yield}

\subsubsection{Plant height of clover}

Data presented in Table (3) show the effect of trend was true in the second season. Results are in general agreement with those obtained by Soliman (2002).

\subsubsection{Fresh and dry weights of clover}

As for fresh and dry weights of clover plants (ton/fed), the results indicated that un-treated and un-infested treatment recorded the highest values (12.92 and 12.94 ton/fed) as fresh weight and (1.62 and 1.71 ton/fed) as the dry weigh at the third cut in the first and second seasons, respectively. On the other hand the least fresh and dry weight was obtained by plants infested with dodder. This holds fairly true in the three cuts.

Data also, revealed that all the studied herbicide treatments significantly increased the fresh and dry weights of clover plants as

Table (2): Effect of weed control treatments on fresh and dry weights of dodder (g/m2) in 2013/ 2014 and 2014/ 2015 seasons.

\begin{tabular}{|c|c|c|c|c|c|c|c|c|c|}
\hline \multirow{3}{*}{$\begin{array}{l}\text { Weed control } \\
\text { treatments }\end{array}$} & \multirow{3}{*}{$\begin{array}{l}\text { Rate } \\
\text { (l/fed) }\end{array}$} & \multicolumn{8}{|c|}{$2013 / 2014$} \\
\hline & & \multicolumn{2}{|c|}{ First cut } & \multicolumn{2}{|c|}{ Second cut } & \multicolumn{4}{|c|}{ Third cut } \\
\hline & & F.W & D.W. & D.W. & D.W. & F.W. & $\mathbf{R} \%$ & D.W. & $\mathbf{R} \%$ \\
\hline glyphosate & 0.07 & 294.6 & 22.6 & 42.5 & 3.8 & 36.5 & 97.71 & 2.7 & 98.90 \\
\hline glyphosate & 0.1 & 268.2 & 19.8 & 25.7 & 1.9 & 17.8 & 98.88 & 1.4 & 99.43 \\
\hline Propyzamide & 0.75 & 44.3 & 3.9 & 150.3 & 10.8 & 270.3 & 83.04 & 19.8 & 91.95 \\
\hline propyzamide & 1.0 & 42.5 & 3.7 & 109.2 & 9.2 & 190.6 & 88.04 & 14.4 & 94.15 \\
\hline Hand pulling & $\begin{array}{l}\text { After } \\
\text { cutting }\end{array}$ & 641.4 & 46.7 & 708.4 & 49.3 & 962.6 & 39.62 & 126.3 & 48.70 \\
\hline \multicolumn{2}{|l|}{ Infested control } & 1260.5 & 181.9 & 1525.6 & 196.6 & 1594.4 & - & 246.2 & - \\
\hline \multicolumn{2}{|c|}{ Un-infested control } & - & - & - & - & - & - & - & - \\
\hline \multicolumn{2}{|c|}{ LSD at $5 \%$} & 87.34 & 4.41 & 59.36 & 5.31 & 39.55 & & 3.49 & \\
\hline & \multicolumn{9}{|c|}{$2014 / 2015$} \\
\hline glyphosate & 0.07 & 384.5 & 32.6 & 169.4 & 15.3 & 72.8 & 97.20 & 6.8 & 96.08 \\
\hline glyphosate & 0.1 & 372.4 & 28.8 & 151.7 & 12.4 & 43.7 & 98.32 & 3.6 & 97.92 \\
\hline Propyzamide & 0.75 & 73.7 & 5.8 & 126.6 & 9.4 & 210.2 & 91.92 & 17.3 & 90.03 \\
\hline propyzamide & 1.0 & 50.3 & 3.9 & 95.5 & 6.43 & 136.4 & 94.76 & 9.8 & 94.35 \\
\hline Hand pulling & $\begin{array}{c}\text { After } \\
\text { cutting }\end{array}$ & 843.2 & 60.2 & 981.4 & 69.4 & 1098.5 & 57.82 & 77.2 & 55.52 \\
\hline \multicolumn{2}{|l|}{ Infested control } & 2016.4 & 135.4 & 2325.2 & 155.7 & 2604.4 & - & 173.6 & - \\
\hline \multicolumn{2}{|c|}{ Un-infested control } & - & - & - & - & - & - & - & - \\
\hline \multicolumn{2}{|l|}{ LSD at $5 \%$} & 79.43 & 6.92 & 71.33 & 7.05 & 29.64 & & 3.17 & \\
\hline
\end{tabular}

weed control treatments on plant height $(\mathrm{cm})$ at the first, second and third cutting, where it could be noticed that all tested herbicides increased the plant height at the three cuts as compared with the infested control treatment.

Data also, revealed that the application of propyzamide at a rate of $1.0 \mathrm{l} / \mathrm{fed}$ gave the tallest plants, followed by propyzamide at a rate $0.75 \mathrm{l} / \mathrm{fed}$, glyphosate at a rate of $0.1 \mathrm{l} / \mathrm{fed}$ and glyphosate at a rate of $0.07 \mathrm{~L} / \mathrm{fed}$. The same compared to infested control treatment. These findings were true after three cuts, and this effect was constant from season to another. These results are in agreement with those obtained by Al-Shair (1986) and Soliman (2002 and 2009).

The most effective treatment for increasing fresh and dry weights of clover plants was obtained from propyzamide at the rate of 1.0 lfed which recorded the fresh weight of 7.90, 11.79 and 11.85 ton/fed in the first season, and 
8.06, 11.72 and 11.73 ton/fed in the second season at the three cuts, respectively, as compared with the infested control treatment, followed by propyzamide at a rate of $0.75 \mathrm{~L} / \mathrm{fed}$, glyphosate at a rate of $0.1 \mathrm{l} / \mathrm{fed}$ and glyphosate at the rate $0.07 \mathrm{l} / \mathrm{fed}$. The superiority of these herbicides against dodder ( $C$. planiflora) could be attributed to the continuous destroying effect on the sequential application. Hand combing treatment recorded the least fresh and dry weights (5.50 and 0.87), (7.17 and 1.11) and (8.44 and 1.23 ton/fed) in the first season and (5.96 and 0.92), (7.69 and 1.08) and (8.09 and $1.17 \mathrm{ton} / \mathrm{fed}$ ) in the second season at the three cuts, respectively, compared with the used herbicides.

It is striking that all the tested herbicides increased the fresh and dry weights of clover plants as compared to the infested control treatment.

\subsubsection{Seed yield of clover}

Data in Table (3) showed that weed control treatments had a significant effect on seed yield in both seasons. The influence of such treatment on seed yield had the same trend of the plant height, fresh and dry weights of clover plants. reached ( 125.93 and $169.98 \mathrm{~kg} / \mathrm{fed}$ ) in the two seasons, respectively, compared with the uninfested and un-treated. These results are similar to those obtained by Feesehaie (1992) and Soliman (2009) who reported that yield losses due to Cuscuta spp. often are serious, but the most sever infestation can cause up to complete crop failure. Also, these results agreed with Soliman (2002).

Comparing the results between hand combing treatment and the tested herbicides generally, indicated that the highest increases in seed yield were achieved from herbicide propyzamide at the rate $(1.0 \mathrm{ad} 0.75 \mathrm{l} / \mathrm{fed})$ and glyphosate at the rate $(0.1$ and $0.07 \mathrm{l} / \mathrm{fed})$. While hand combing treatment gave the lowest seed yield as compared with all tested herbicides. These results showed that single hand combing was unuseful in dodder control. This means only suitable to avoid competition of dodder weed due to their low weed population density. All tested herbicides increased the seed yield of clover with different rotations as compared to the infested control treatment and assured the importance of using of suitable herbicides due to the excepted problem of dodder weed.

Table (3): Effect of weed control treatments on Egyptian clover ( plant height, cm; forage yield (ton /fed ) and seed yield ( kg / fed ) in 2013 / 2014 and 2014 / 2015 seasons .

\begin{tabular}{|c|c|c|c|c|c|c|c|c|c|c|c|}
\hline \multirow{3}{*}{$\begin{array}{l}\text { Weed control } \\
\text { treatments }\end{array}$} & \multirow{3}{*}{$\begin{array}{l}\text { Rate } \\
\text { (l/fed) }\end{array}$} & \multicolumn{10}{|c|}{$2013 / 2014$} \\
\hline & & \multicolumn{3}{|c|}{ First cut } & \multicolumn{3}{|c|}{ Second Cut } & \multicolumn{3}{|c|}{ Third cut } & \multirow{2}{*}{$\begin{array}{c}\text { Seed yield } \\
\text { (kg / fed) }\end{array}$} \\
\hline & & P.H. & F.W. & D.W. & P.H. & F.W. & D.W. & P.H. & F.W. & D.W. & \\
\hline glyphosate & 0.07 & 68.8 & 7.93 & 0.92 & 85.4 & 11.10 & 1.28 & 86.9 & 11.96 & 1.46 & 266.94 \\
\hline glyphosate & 0.1 & 67.3 & 7.82 & 0.97 & 86.0 & 11.43 & 1.19 & 83.8 & 11.67 & 1.36 & 292.39 \\
\hline propyzamide & 0.75 & 67.5 & 8.09 & 1.03 & 87.5 & 12.05 & 1.46 & 86.3 & 12.21 & 1.51 & 316.42 \\
\hline propyzamide & 1.0 & 69.8 & 7.90 & 1.01 & 88.5 & 11.79 & 1.24 & 91.5 & 11.85 & 1.42 & 351.51 \\
\hline Hand pulling & $\begin{array}{l}\text { After } \\
\text { cutting }\end{array}$ & 57.5 & 5.50 & 0.87 & 71.2 & 7.17 & 1.11 & 79.3 & 8.44 & 1.23 & 263.57 \\
\hline \multicolumn{2}{|l|}{ Infested control } & 45.8 & 4.95 & 0.85 & 69.1 & 6.55 & 1.04 & 73.5 & 6.86 & 1.18 & 201.38 \\
\hline \multicolumn{2}{|c|}{ Un-infested control } & 70.8 & 8.34 & 1.08 & 90.5 & 12.58 & 1.78 & 93.6 & 12.92 & 1.62 & 289.50 \\
\hline \multicolumn{2}{|c|}{ LSD at $5 \%$} & 3.3 & 1.57 & 0.62 & 2.5 & 2.23 & 0.71 & 4.7 & 2.47 & 0.18 & 21.58 \\
\hline & & \multicolumn{10}{|c|}{$2014 / 2015$} \\
\hline glyphosate & 0.07 & 61.90 & 7.90 & 0.93 & 87.64 & 11.48 & 1.05 & 85.73 & 11.84 & 1.31 & 233.25 \\
\hline glyphosate & 0.1 & 60.35 & 7.89 & 1.01 & 85.13 & 11.72 & 1.16 & 82.03 & 11.56 & 1.39 & 241.93 \\
\hline propyzamide & 0.75 & 63.55 & 8.16 & 1.01 & 87.84 & 11.92 & 1.36 & 89.46 & 12.02 & 1.50 & 263.81 \\
\hline propyzamide & 1.0 & 61.75 & 8.06 & 0.95 & 79.48 & 11.72 & 1.23 & 81.97 & 11.37 & 1.43 & 312.44 \\
\hline Hand pulling & $\begin{array}{l}\text { After } \\
\text { cutting }\end{array}$ & 59.30 & 5.96 & 0.92 & 70.26 & 7.69 & 1.08 & 73.75 & 8.09 & 1.17 & 209.54 \\
\hline \multicolumn{2}{|l|}{ Infested control } & 57.25 & 5.37 & 0.90 & 68.34 & 6.05 & 0.92 & 72.34 & 6.86 & 1.11 & 198.74 \\
\hline \multicolumn{2}{|l|}{ Un-infested control } & 73.95 & 8.89 & 1.14 & 93.07 & 12.82 & 1.69 & 91.52 & 12.94 & 1.71 & 379.52 \\
\hline \multicolumn{2}{|c|}{ LSD at 5\% } & 3.34 & 1.32 & 0.18 & 4.63 & 1.58 & 0.20 & 5.11 & 2.10 & 0.16 & 23.78 \\
\hline
\end{tabular}

$\begin{array}{lll}\text { P.H. = plant height . } & \text { F.W. }=\text { fresh weight }(\text { ton } / \text { fed }) & \text { D.W. }=\text { dry weight }(\text { ton } / \text { fed })\end{array}$

The hand pulling treatment recorded the lowest seed yield ( 263.57 and $209.54 \mathrm{~kg} / \mathrm{fed}$ ) where seed yield losses from competition

\subsection{Effect of herbicides on crude protein content}


Data presented in Table (4) showed the effect of different herbicidal treatments as well as dodder weed competition on crude protein of clover plants. The obtained results clearly revealed that the parasitic weed caused a great reduction in crude protein of clover plants.

Also, the results tabulated revealed that the herbicide glyphosate had the moderate effect in inhibition of crude protein content, while the herbicide propyzamide had the least effect in inhibition of crude protein in the three cuts. These results are in the line with the results of Abd El-Wahed (1996) and Soliman (2009) who found that glyphosate at the rate of $100 \mathrm{~g}$ a.i./fed had a moderate effect on crude protein in Egyptian clover, while the rate $50 \mathrm{~g}$ a.i./fed had a slight effect on crude protein content as compared with the control treatments. Also, these results agreed with Soliman (2002) who reported that glyphosate herbicide showed moderate effect as an inhibitory agent for crude protein, while propyzamide had the least effect in inhibition of crude protein after thirty five days from application.

\subsection{Effect of herbicides on chlorophyll and carotene content}

Data presented in Table (5) clearly showed that chlorophyll and carotene were significantly affected by dodder and different herbicide treatments. This was true in the three cuts.

The untreated (un-infested) clover plants gave significantly the highest chlorophyll a and b when compared with the infested control treatment. No significant differences among the other treatments were found. The same trend was obtained in the three cuts with slight differences.

Regarding carotene content, the data indicated that controlling dodder by herbicides increased carotene content as compared to healthy clover plants. However, differences among the herbicidal treats were insignificant. Results are in general agreement with those reported by Ahmed et al. (1995) and Soliman (2002 and 2009).

\subsection{Effect of herbicides on nodulation}

Data in Table (6) showed that all postemergence treatments (glyphosate) were found to increase both the number of nodules per plant and their dry weight over the untreated control. In contrast, the propyzamide used as preemergence was found to reduce slightly both the number and dry weight of nodules at three cuts in both growing seasons. Kust and Struckmeyer (1971) in studying the effect of some preemergence herbicides on the nodulation of porrillo cultivar was increased by alachlor and decreased by other herbicides.

Also, the results in Table (6) showed that glyphosate at the rate of $0.07 \mathrm{l} / \mathrm{fed}$ gave the highest values of number and dry weights of nodules. The number of nodules reached ( 24.41 and 23.87), whereas, the dry weight of nodules amounted to $(0.46$ and $0.44 \mathrm{~g} /$ plant $)$ in the first and second seasons, respectively, followed by glyphosate at the rate of $0.1 \mathrm{l} / \mathrm{fed}$, propyzamide at the rate of $0.75 \mathrm{l} / \mathrm{fed}$ and propyzamide at the rate of $1.0 \mathrm{l} / \mathrm{fed}$. These results are in general agreement with those obtained by Ozair and Mosheir (1989) who found that pre-emergence herbicides reduced nodulation in soybean plants. Abd El-Hamid and El-Metwally (2008) indicated that herbicides applied at higher doses reduced fresh and dry weight of nodules compared to hand hoeing and un-weeded treatments.

\subsection{Herbicides residues in soil and clover plants}

Data in Table (7) and Fig. (1) showed the behavior of glyphosate in the soil and clover plants. The concentration of glyphosate in the soil after application (zero time) was (7.27 and $8.58 \mathrm{ppm}$ ) for the first and second seasons, respectively. The time for $50 \%$ loss of initial glyphosate in the soil were (15 and 17 days) in both growing seasons, respectively. and reached to $(0.19$ and $0.16 \mathrm{ppm})$ and (97.39 and $98.14 \%$ loss) after 4o days of application for the two seasons. Amounts of (11.94 and $12.31 \mathrm{ppm}$ ) were found in clover plants at the first and second seasons, respectively at zero time, then after 30 days from application the concentrations of glyphosate in clover plants were (1.88 and $1.45 \mathrm{ppm}$ ) and ( 84.26 and $88.22 \%$ loss) of the initial glyphosate concentrations in the clover plants at the first and second seasons, respectively. The glyphosate residue became undetected in clover plants. These results were in agreement with those of Ramesh and Beena (2008) who found that the residues of postemergence herbicides were not detected in the soil after 78 days from application at the recommended rates. 
Table (4): Effect of weed control treatments on crude protein content ( $\mathrm{mg} / \mathrm{g}$ ) of clover plants after three cuts in 2013/2014 and 2014 /2015 seasons.

\begin{tabular}{|c|c|c|c|c|c|c|c|}
\hline \multirow{3}{*}{$\begin{array}{l}\text { Crude protein } \\
\text { contents } \\
(\mathrm{mg} / \mathrm{g}) \text { of } \\
\text { clover plants }\end{array}$} & \multicolumn{7}{|c|}{$2013 / 2014$} \\
\hline & \multicolumn{7}{|c|}{ Weed control treatments } \\
\hline & 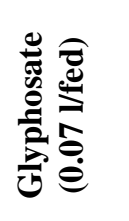 & 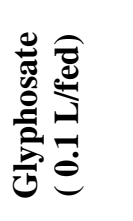 & 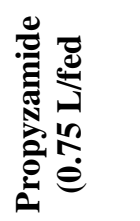 & 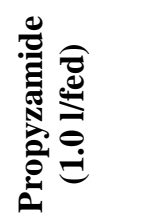 & 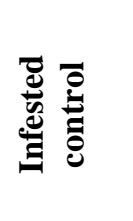 & 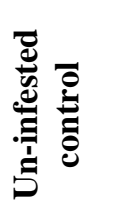 & 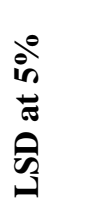 \\
\hline $\begin{array}{c}\mathbf{m g} / \mathbf{g} \\
\text { (First cut) }\end{array}$ & 15.75 & 15.19 & 17.38 & 16.27 & 5.67 & 19.36 & 7.78 \\
\hline $\begin{array}{c}\mathrm{mg} / \mathrm{g} \\
\text { (Second cut) }\end{array}$ & 17.46 & 16.47 & 17.73 & 17.04 & 5.12 & 19.55 & 8.76 \\
\hline $\begin{array}{c}\mathrm{mg} / \mathrm{g} \\
\text { (third cut) }\end{array}$ & 17.86 & 16.72 & 18.11 & 17.67 & 3.84 & 19.85 & 8.35 \\
\hline \multicolumn{8}{|c|}{$2014 / 2015$} \\
\hline $\begin{array}{c}\mathbf{m g} / \mathbf{g} \\
\text { (First cut) }\end{array}$ & 17.93 & 17.02 & 19.54 & 18.74 & 6.81 & 21.95 & 8.27 \\
\hline $\begin{array}{c}\mathrm{mg} / \mathrm{g} \\
\text { (Second cut) }\end{array}$ & 18.33 & 17.15 & 19.73 & 18.89 & 6.81 & 23.47 & 9.28 \\
\hline $\begin{array}{c}\mathrm{mg} / \mathrm{g} \\
\text { (third cut) }\end{array}$ & 18.82 & 17.55 & 20.63 & 19.74 & 7.26 & 23.98 & 9.21 \\
\hline
\end{tabular}

$\mathrm{Mg} / \mathrm{g}=$ weight of total protein determined as $\mathrm{mg}$ per gm of clover plants.

Table (5) : Effect of herbicides on chlorophyll and carotene ( $\mathrm{mg} / \mathrm{g})$ fresh weight of clover plants after three cuts in $2013 / 2014$ and $2014 / 2015$ seasons.

\begin{tabular}{|c|c|c|c|c|c|c|c|c|c|c|}
\hline \multirow{4}{*}{$\begin{array}{l}\text { Weed control } \\
\text { treatments }\end{array}$} & \multirow{4}{*}{$\begin{array}{c}\text { Rate } \\
\text { (l/fed) }\end{array}$} & \multicolumn{9}{|c|}{ 2013/2014 } \\
\hline & & \multicolumn{3}{|c|}{ First cut } & \multicolumn{3}{|c|}{ Second cut } & \multirow{2}{*}{\multicolumn{2}{|c|}{$\begin{array}{c}\text { Third cut } \\
\text { chlorophyll }\end{array}$}} & \multirow[t]{3}{*}{ carotene } \\
\hline & & \multicolumn{2}{|c|}{ Chlorophyll } & \multirow[t]{2}{*}{ carotene } & \multicolumn{2}{|c|}{ Chlorophyll } & \multirow[t]{2}{*}{ carotene } & & & \\
\hline & & $\mathbf{a}$ & b & & $\mathbf{a}$ & b & & $\mathbf{a}$ & b & \\
\hline glyphosate & 0.07 & 1.310 & 0.766 & 0.915 & 1.698 & 0.546 & 1.088 & 1.321 & 0.580 & 1.140 \\
\hline glyphosate & 0.1 & 1.210 & 0.759 & 0.948 & 1.576 & 0.446 & 1.066 & 1.327 & 0.534 & 1.155 \\
\hline propyzamide & 0.75 & 1.356 & 0.721 & 0.797 & 1.906 & 0.991 & 1.000 & 1.627 & 0.688 & 1.040 \\
\hline propyzamide & 1.0 & 1.331 & 0.772 & 0.853 & 1.777 & 0.712 & 1.066 & 1.424 & 0.639 & 1.072 \\
\hline \multicolumn{2}{|c|}{ Infested control } & 0.872 & 0.331 & 1.040 & 0.992 & 0.331 & 1.323 & 1.201 & 0.475 & 1.271 \\
\hline \multicolumn{2}{|c|}{ Un-infested control } & 1.550 & 0.910 & 0.548 & 1.909 & 1.053 & 0.956 & 1.938 & 0.727 & 0.951 \\
\hline \multicolumn{2}{|c|}{ LSD at $5 \%$} & 0.524 & 0.427 & 0.437 & 0.751 & 0.449 & 0.335 & 0.616 & 0.217 & 0.270 \\
\hline & \multicolumn{10}{|c|}{2014 / 2015} \\
\hline glyphosate & 0.07 & 1.294 & 0.741 & 0.900 & 1.678 & 0.537 & 1.065 & 1.327 & 0.589 & 1.137 \\
\hline glyphosate & 0.1 & 1.214 & 0.751 & 0.969 & 1.581 & 0.456 & 1.079 & 1.332 & 0.551 & 1.152 \\
\hline propyzamide & 0.75 & 1.433 & 0.713 & 0.788 & 1.916 & 0.983 & 1.011 & 1.633 & 0.672 & 1.026 \\
\hline propyzamide & 1.0 & 1.312 & 0.758 & 0.861 & 1.763 & 0.702 & 1.072 & 1.410 & 0.614 & 1.064 \\
\hline \multicolumn{2}{|c|}{ Infested control } & 0.815 & 0.336 & 1.063 & 0.983 & 0.339 & 1.308 & 1.721 & 0.473 & 1.212 \\
\hline \multicolumn{2}{|c|}{ Un-infested control } & 1.562 & 0.924 & 0.552 & 1.914 & 1.038 & 0.943 & 1.928 & 0.713 & 0.939 \\
\hline \multicolumn{2}{|c|}{ LSD at $5 \%$} & 0.613 & 0.492 & 0.471 & 0.857 & 0.437 & 0.246 & 0.608 & 0.312 & 0.229 \\
\hline
\end{tabular}

$\mathrm{Mg} / \mathrm{g}=$ Weight of chlorophyll determined as $\mathrm{mg}$ per gm of leaves of clover plants. 


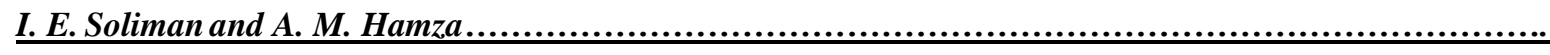

Table (6) : Effect of tested herbicides on the number and dry weight of nodules per clover plant (g/plant) after three cuts in 2013 / 2014 and 2014 / 2015 seasons .

\begin{tabular}{|c|c|c|c|c|c|c|c|c|c|}
\hline \multirow{3}{*}{$\begin{array}{c}\text { Weed control } \\
\text { treatments }\end{array}$} & \multirow{3}{*}{$\begin{array}{c}\text { Rate } \\
\text { (l/fed) }\end{array}$} & \multicolumn{8}{|c|}{$2013 / 2014$} \\
\hline & & \multicolumn{4}{|c|}{ Number of nodules } & \multicolumn{4}{|c|}{ Dry weight of nodules (g/plant) } \\
\hline & & First cut & $\begin{array}{l}\text { Second } \\
\text { cut }\end{array}$ & Third cut & Mean & $\begin{array}{l}\text { First } \\
\text { cut }\end{array}$ & $\begin{array}{c}\text { Second } \\
\text { cut }\end{array}$ & Third cut & Mean \\
\hline glyphosate & 0.07 & 17.81 & 22.72 & 32.72 & 24.41 & 0.26 & 0.43 & 0.71 & 0.46 \\
\hline glyphosate & 0.1 & $\mathbf{1 7 . 7 2}$ & 22.36 & 31.32 & 23.80 & 0.25 & 0.39 & 0.68 & 0.44 \\
\hline propyzamide & 0.75 & 16.23 & 21.41 & 29.80 & 22.48 & 0.24 & 0.33 & 0.65 & 0.41 \\
\hline propyzamide & 1.0 & 16.14 & 20.44 & 29.51 & 22.03 & 0.23 & 0.31 & 0.64 & 0.39 \\
\hline \multicolumn{2}{|c|}{ Un-infested control } & $\mathbf{1 7 . 3 2}$ & 23.38 & 35.46 & 25.39 & 0.28 & 0.44 & 0.82 & 0.51 \\
\hline \multicolumn{2}{|c|}{ LSD at $5 \%$} & 3.04 & 2.13 & 2.56 & & 0.10 & 0.13 & 0.23 & \\
\hline & & \multicolumn{8}{|c|}{$2014 / 2015$} \\
\hline glyphosate & 0.07 & 16.11 & 22.16 & 32.54 & 23.60 & 0.25 & 0.38 & 0.69 & 0.44 \\
\hline glyphosate & 0.1 & 15.74 & 21.42 & 31.62 & 22.92 & 0.27 & 0.40 & 0.61 & 0.43 \\
\hline propyzamide & 0.75 & 15.56 & 20.13 & 29.35 & 21.68 & 0.27 & 0.39 & 0.59 & 0.41 \\
\hline propyzamide & 1.0 & 14.72 & 18.85 & 27.97 & 20.48 & 0.26 & 0.36 & 0.56 & 0.39 \\
\hline \multicolumn{2}{|c|}{ Un-infested control } & 15.73 & 22.47 & 33.81 & 24.00 & 0.26 & 0.42 & 0.73 & 0.47 \\
\hline \multicolumn{2}{|c|}{ LSD at $5 \%$} & 3.14 & 2.35 & 2.83 & & 0.18 & 0.17 & 0.31 & \\
\hline
\end{tabular}

Table (7): Stability of Roundup (glyphosate) herbicide in the soil and clover plants under field conditions (ppm) in 2013/14 and 2014/15 seasons.

\begin{tabular}{|c|c|c|c|c|}
\hline \multirow{2}{*}{$\begin{array}{l}\text { Samples time } \\
\text { (days) }\end{array}$} & \multicolumn{4}{|c|}{$2013 / 14$} \\
\hline & Soil & $\begin{array}{c}\text { Loss } \\
\%\end{array}$ & Clover plants & $\begin{array}{c}\text { Loss } \\
\%\end{array}$ \\
\hline Zero & 7.27 & - & 11.94 & - \\
\hline 10 & 6.12 & 15.81 & 9.08 & 23.95 \\
\hline 20 & 3.06 & 57.91 & 4.13 & 65.41 \\
\hline 30 & 1.13 & 84.46 & 1.88 & 84.26 \\
\hline 40 & 0.19 & 97.39 & 0.04 & 99.67 \\
\hline 50 & UND & - & UND & - \\
\hline \multirow[t]{2}{*}{ T 0.5 (days) } & \multicolumn{2}{|c|}{50.79} & \multicolumn{2}{|c|}{11.94} \\
\hline & \multicolumn{4}{|c|}{$2014 / 15$} \\
\hline Zero & 8.58 & - & 12.31 & - \\
\hline 10 & 6.02 & 30.07 & 10.24 & 16.81 \\
\hline 20 & 3.32 & 61.31 & 4.13 & 66.45 \\
\hline 30 & 1.17 & 86.37 & 1.45 & 88.22 \\
\hline 40 & 0.16 & 98.14 & 0.06 & 99.52 \\
\hline 50 & UND & - & UND & - \\
\hline T 0.5 (days) & \multicolumn{2}{|c|}{48.33} & \multicolumn{2}{|c|}{37.23} \\
\hline \multicolumn{3}{|c|}{$\begin{array}{l}\text { Zero time: after } 24 \text { hours from application. } \\
\text { UND: undetectable }\end{array}$} & \multicolumn{2}{|l|}{ T 0.5 : half lives } \\
\hline
\end{tabular}

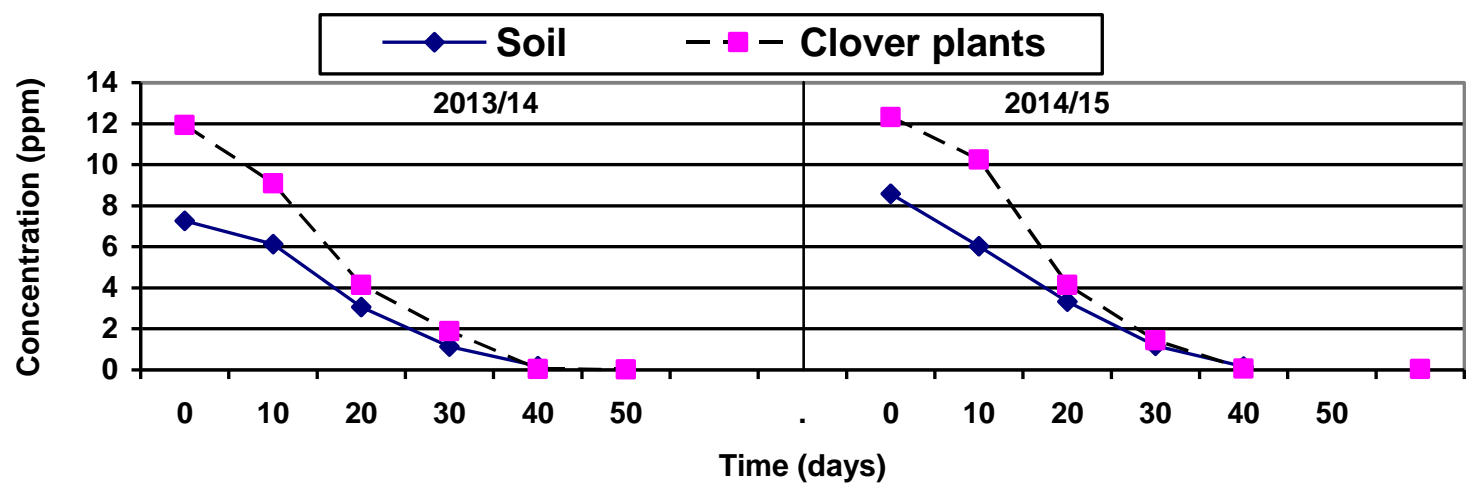

Fig. ( 1) : Stability of Round up (glyphosate) herbicide in the soil and clover plants under field conditions (ppm) in 2013/14 and 2014/15 seasons. 
Table (8) and Fig. (2) showed the residual behavior of propyzamide in the soil and clover plants under field conditions. At zero time, the concentrations of propyzamide in the soil were (15.70 and $15.67 \mathrm{ppm}$ ) in the first and second seasons, respectively. After 30 days about (54.70 and $55.20 \%$ ) loss of the initial propyzamide in the soil were detected. At the end of the experiment after 60 days from application about (98.91 and 99.10\%) loss of initial propyzamide in the soil in both seasons. The time for $50 \%$ loss of initial propyzamide in the soil was shorter in the first season than the second season (26 and 28 days). On the other hand, the concentration of propyzamide at zero time in clover plants were 9.21 in first season and $8.11 \mathrm{ppm}$ in second season.
After 30 days from application propyzamide residue was 79.62 and $77.17 \%$ loss of the initial propyzamide in the clover plants of both growing seasons. The half lives of propyzamide in clover plants were ( 23 and 26 days) for the first and second season, respectively. At the end of experiment (60 days), there were no propyzamide residues in the clover plants in both growing seasons.

From the previous results, it could be deduced that glyphosate and propyzamide herbicides degraded rapidly in the soil and clover plants. There are active herbicides against dodder weed in clover fields. Therefore, the above herbicides can be recommended for using without any harm on the clover plants or on the soil.

Table (8): Stability of Kerb Flow (propyzamide) herbicide in soil and clover plants under field conditions $(\mathrm{ppm})$ in 2013/14 and 2014/15 seasons.

\begin{tabular}{|c|c|c|c|c|}
\hline \multirow{2}{*}{$\begin{array}{l}\text { Samples time } \\
\text { (days) }\end{array}$} & \multicolumn{4}{|c|}{$2013 / 14$} \\
\hline & Soil & $\begin{array}{c}\text { Loss } \\
\%\end{array}$ & Clover plants & $\begin{array}{c}\text { Loss } \\
\%\end{array}$ \\
\hline Zero & 15.70 & - & - & - \\
\hline 10 & 13.07 & 16.85 & 1.57 & - \\
\hline 20 & 10.74 & 31.67 & 0.63 & 59.88 \\
\hline 30 & 7.12 & 54.70 & 0.32 & 79.62 \\
\hline 40 & 3.09 & 80.84 & 0.11 & 93.00 \\
\hline 50 & 0.97 & 93.82 & UND & - \\
\hline 60 & 0.17 & 98.91 & - & - \\
\hline \multirow[t]{2}{*}{ T 0.5 (days) } & \multicolumn{2}{|c|}{50.79} & \multicolumn{2}{|c|}{11.94} \\
\hline & \multicolumn{4}{|c|}{$2014 / 15$} \\
\hline Zero & 15.67 & - & - & - \\
\hline 10 & 12.73 & 18.76 & 1.27 & - \\
\hline 20 & 10.46 & 33.24 & 0.57 & 55.12 \\
\hline 30 & 7.02 & 55.20 & 0.29 & 77.17 \\
\hline 40 & 3.01 & 80.80 & 0.09 & 92.92 \\
\hline 50 & 0.62 & 96.04 & UND & - \\
\hline 60 & 0.14 & 99.10 & - & - \\
\hline T 0.5 (days) & \multicolumn{2}{|c|}{48.33} & \multicolumn{2}{|c|}{37.23} \\
\hline
\end{tabular}

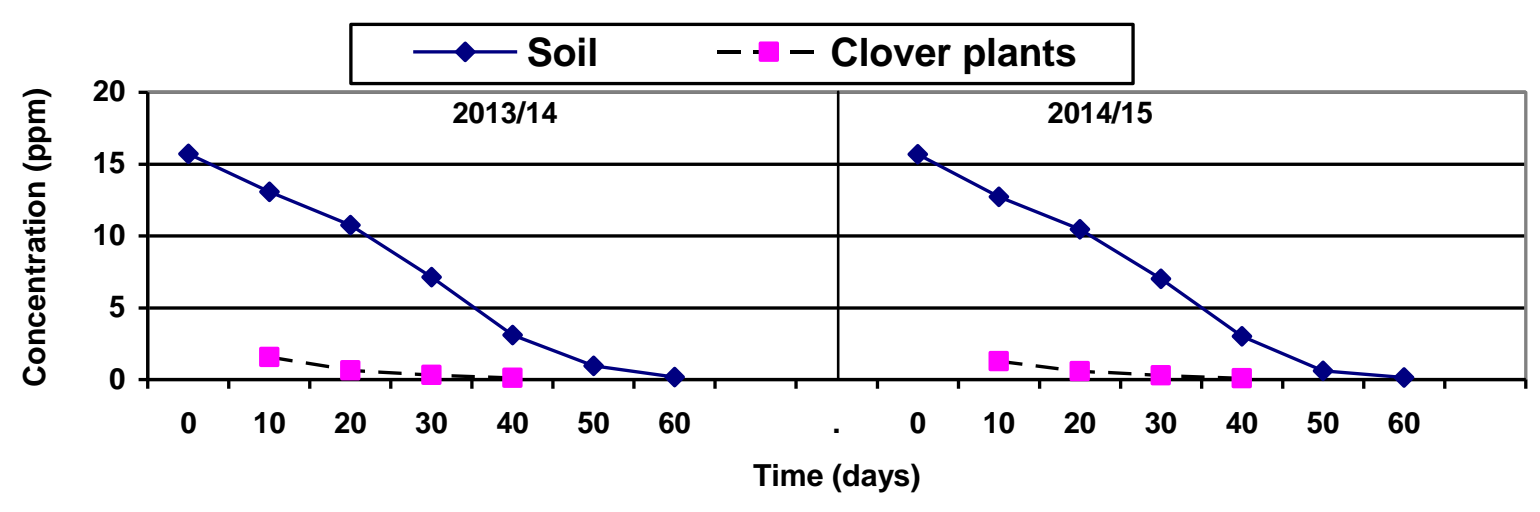

Fig. (2): Stability of Kerb flow (propyzamide) herbicide in soil and clover plants under field conditions (ppm) in 2013/14 and 2014/15 seasons. 


\section{Conclusion}

Under the conditions of the present investigation, using glyphosate at the rate 0.07 $1 /$ fed or propyzamide at the rate $1.01 / \mathrm{fed}$, can be recommended as the best treatment for dodder weed control in Egyptian clover and without any harm effect on clover plants or on the soil.

\section{REFERENCES}

Abd Alla F.M., Hamouda F.M., El-Shandidy S.E. and Salem K.G. (1985). Effect of certain herbcides on Rhizobium, soybean symbiosis and multiplication of Azotobacter in the rhizosohere. J . Agric. Res. Tanta Univ., 11 (1): 213 - 221.

Abd El-Hamid M.T. and El-Metwally I. M. (2008). Shaping the future of field crops in Egypt. Proceeding The second Field Crops Conference Egypt. 14 - 16 Oct. 377 -390 .

Abd El-Wahed R. (1996). Studies on the effect of certain herbicides for dodder Cuscuta spp. control in certain leguminous crops. Ph.D. thesis, Fac. of Agric. Cairo Univ., Egypt.

Ahmed S.A., Hassan A.A.A. and Gawesh S. S.M. (1995). Effect of some herbicides on control of dodder in clover plants. J. Agric. Sci., Mansoura Univ., 20(10): 4271 $-4279$.

Al-Menoufi O.A. and Hassan M. T. H. (1977). Studies on the parasitism of Cuscuta spp. Series2. The effect of dodder (Cuscuta planiflora. Ten) on production and chemical composition of Egyptian clover (Trifolium alexandrinum L.). Alex. J., Agric. Res., 25 (2): 337-341.

Al-Shair S. A. (1986). Effect of dodder Cuscuta spp. on some Egyptian crops. Alex. J. Agric. Res., 31 (2): 481.

A.O.A.C. (1980). Official methods of analysis of the association official analytical chemists $14^{\text {th }}$ Ed., Washington D.C., USA.

Bhan V. M. and Balyan R. S. (1982). Toxicity of glyphosate to certain rabi crops. Pesticides, 16 (10): 31-32 Dep. Agron., Haryana Agric., Univ., Hissar 125004, Hayana, India (C.F. Computer Search).

El-Beit I.O., Wheelock J.V. and Cotton D.E. (1978). Separation and characterization of dimethoate metabolites developing in soil and alkaline solution. J. Environ. Studies,
12: 215-225.

El-Hawary F., El-Gazar T. M. and Hammouda F. M. (1986). Effect of selected herbicides on Rhizobium legumin Aswan in pure culture and its symbiosis with pea under field conditions. J. Agric Sci. Mansoura Univ. 11 (3): 1089-1095

Fessehaie, R. (1992). Review of (Cuscuta spp.) problems and control. Ethiopain Weed Science, Committee, 67 - 78.

Hammouda F. M., El-Shandidy S. E., Salem K. G. and El-Maghraby M. A. (1989). Effect of pronamide herbicide on dodder control, forage green yield and nodulation in berseem clover. The $7^{\text {th }}$ Arab pesticide Conf. Tanta Univ., Egypt, Sept. 11-12, 198.

Heap J. W. (1992). Golden dodder and Silverleaf nightshade. Study tour to USA. Technical Report, Dept. Agric. South Australia, 190, 34 pp (C. F. Computer Search).

Kontsiotou E. K. (1979). Dodder control in alfalfa stands by herbicides. Georgike, Ereuna, 3 (3): 250-285.

Kust C. A. and Struckmeyer, B. E. (1971). Effect of trifluralin on growth, nodulation and anatomy of soybean. Weed Sci., 19 (2): 147 - 152.

Luke M. A., Jerry E. F., Crecory M. D. and Herbert T. M. (1981). Organophosphorus, Organonitrogen and Organohalogen pesticides in proceure, using flame photometric and electrolytic conductivity detectors. J. Assoc. Off. Anal. Chem., 64 (s): 1187-1195.

Molnar F., Gyulai B. and Czepo M. (1998). A new possibility of controlling dodder Cuscuta spp. in the field. Novanyvedelem, 34(7): 379-383.

Ozair C.A. and Moshier L.J. (1989). Effect of post emergence herbicides on nodulation and nitrogen fixation in soybeans (Glycine max). Appl. Agric. Res., 3: 214 - 219.

Ramesh K. and Beena K. (2008). Persistence of clodinafop-propargyl in soil and wheat crop. Environ. Ecol., 26: 48, 2149 - 2151.

Sher M. A. and Shad R. A. (1989). Distribution hosts and means users to control dodder. Progr. Farm., 9 (6): 17 - 20.

Snedecor G. W. and Cochran W. G. (1980). Statistical Methods $6^{\text {th }}$ Ed., Iowa State Univ. Press, Ames Iowa, USA, 325-330.

Soliman I. E. (2002). Herbicidal activity 
evaluation of some herbicides used to control of dodder Cuscuta spp. in some field crops. Ph.D. Thesis, Fac. of Agric. Mansoura Univ., Egypt.

Soliman I. E. (2009). Evaluation of some weed control treatments on dodder Cuscuta planiflora ten. control in Egyptian clover Trifolium alexandrinum L. J. Agric. Sci. Mansoura Univ., Egypt 34(9): 5919-9528.

Soliman I. E. and Abd El-Hamid M. M. (2009). Effect of sowing methods and some weed control treatments on dodder control in clover crop. J. Agric. Sci. Mansoura Univ., Egypt 34(4): 3211-3221.

Sweeny J. P. and Martin M. E. (1961). Stability of chlorophyll in vegetables as effected by pH. Food Tec., 15 (5): 263 - 266.

Tackholem V. (1974). Student flora of Egypt. $2^{\text {nd }}$ Ed. Cairo Univ., Egypt Graphical
Service. Beirut, Lebanon.

Timothy E., Harvey R.G., fawcett R.S. and Jorgensen N. (1978). Improving forage qualtity with pronamide. Proc. North Central Weed Control Conf. 29: 35-36.

Topps J. H. and wain R. L. (1957). Investigation of fungitoxicity of 3 and 5-alkyl saliclanilided and parachloro aniline. Ann. Appl . Biol., 45(3): 506-511.

Vincent J. M. (1970). A manual for the practical study of the root-nodule bacteria. Blackwell scientific publications Oxford and Edinburgh U.K.

Zaki M. A., El-Matwaly H. S. Hassan R. A. and Maillet J. (1998). Studies on dodder Cuscuta spp. Control. Comptes_rendus 6 eme sym. mediterranean EWRS, Montpellier, France, Mai 13-15, 147-150.

$$
\begin{aligned}
& \text { تأثير بعض مبيدات الحشائش على الحامول والمحصول الأخضر والعقد الجذرية } \\
& \text { وتقدير متبقياتها فى نباتات البرسيم والمدصول التربة } \\
& \text { ابراهيم السيد سليمان - أمانى محمود حمزة } \\
& \text { المعمل المركزى لبحوث الحشائش ـ مركز البحوث الزر اعية ـ الجيزة - مصر. }
\end{aligned}
$$

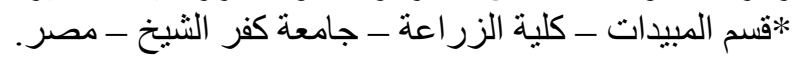

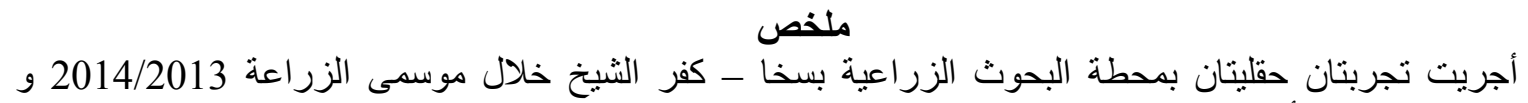

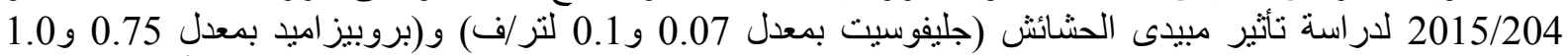

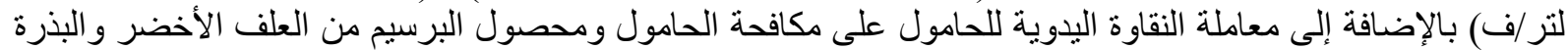

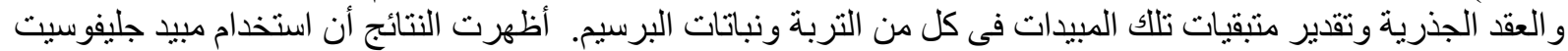

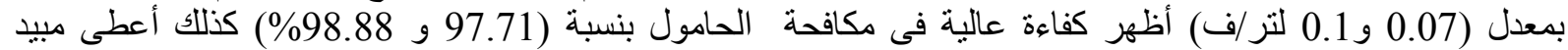

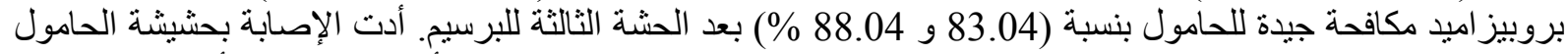

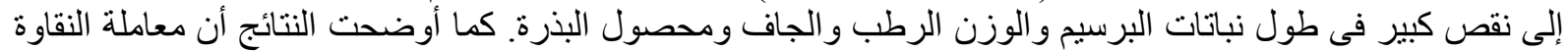

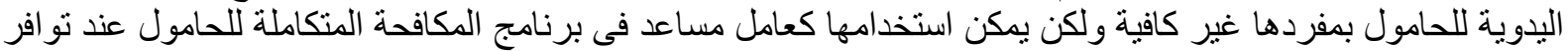

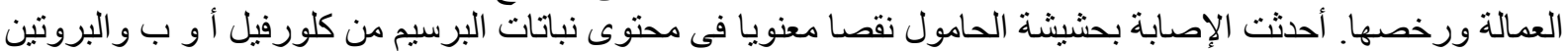

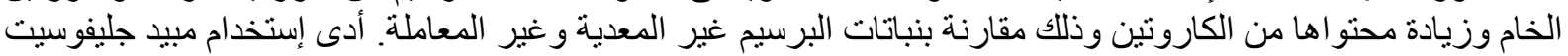

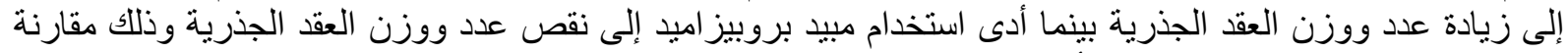

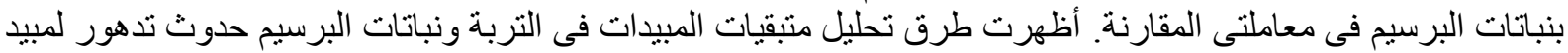

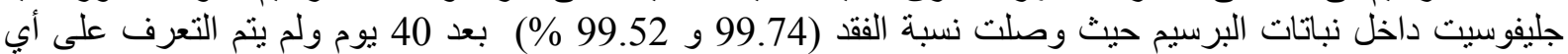

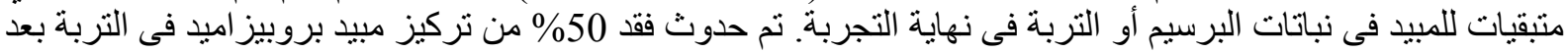

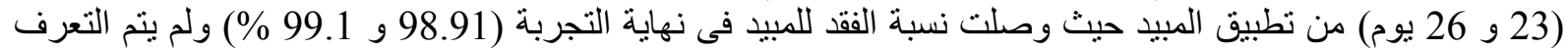
على أي متبقيات للمبيد فى نباتات البرسيم فى نهاية التجربة بعد 60 يوم في كلا موسمي الزر اعثة. 
توصى هذه الدر اسة بامكانية مكافحة حشيشة الحامول فى حقول البرسيم بمبيدات الحشائش كالتالى (جليفوسيث بمعدل 0.07 أو 0.1 لتر/فدان بعد الحش بحوالى بالى 15 يوم) ويفضل المعدل الأقل أو (مبيد بروبيز اميد بمعدل 0.75 أو 0.7.

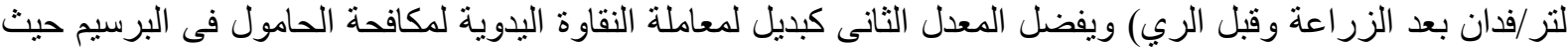

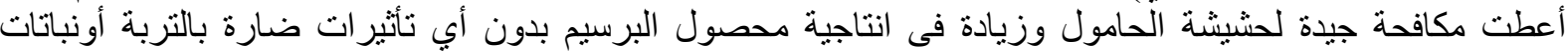
البرسيم.

المجلة العلمية لكلية الزراعة -جامعة القاهرة ـ المجلا (67) العدد الثانى (ابريل 2016 ): 141- 152. 